\title{
A Macabre Exhibit: Ugandan President Museveni's Public Display of the Luwero Triangle War's Human Remains
}

\author{
Onek C. Adyanga \\ Millersville University of Pennsylvania, Millersville, PA, USA \\ Email: onek.adyanga@millersville.edu
}

Received 23 October 2015; accepted 24 December 2015; published 30 December 2015

Copyright (C) 2015 by author and Scientific Research Publishing Inc.

This work is licensed under the Creative Commons Attribution International License (CC BY). http://creativecommons.org/licenses/by/4.0/

(c) (i) 0 pen Access

\section{Abstract}

The public display of human remains has a long history in warfare. Whether for counting enemy losses based on psychological reasoning or demonizing the perpetrators of the violence, exhibiting human remains has potently served a variety of political, educational and propaganda aims. In Uganda, President Yoweri Kaguta Museveni has exhibited human remains for political and military purposes numerous times. Museveni has frequently displayed the Luwero Triangle War's human remains to help secure his National Resistance Movement and Army's (NRM/A) political legitimacy, consolidate an ethnic-centered regime and harness the support of western governments. He has also exploited the exhibition of the Luwero Triangle War's human remains to stoke ethnic xenophobia and demonization, as well as to stymie the quest for genuine democracy, the rule of law and constitutionalism. The persistent policy of Museveni's NRM/A regime to exhibit the Luwero Triangle War's human remains has shocked the conscience of the people of Uganda and scholars alike who express the need to focus on granting dignity and respect to the rights of the dead and to bring perpetrators to justice. The repeated decision of Museveni's NRM/A regime to exhibit the Luwero Triangle War's human remains undermines any prospects for building a united Uganda based on genuine truth telling and reconciliation.

\section{Keywords}

Insurgency, Counterinsurgency, Civil Wars, Human Remains, Exhibitions, Democracy, Ethnicity and Propaganda

\section{Introduction}

Ugandan President Yoweri Kaguta Museveni’s grotesque policy of exhibiting human remains raises uncom- 
fortable moral and ethical questions for scholars, citizens and visitors to such exhibits. Ever since Museveni's National Resistance Movement and Army (NRM/A) started fighting against Obote's Uganda National Liberation Army (UNLA) in the early 1980s, his men have collected the human remains produced by their war and placed them on public display (Uganda Radio Network, 2012). Whenever the NRM/A's political legitimacy has been threatened, Museveni would organize a guided tour of the human remains for international diplomats, media services and African heads of states and government officials, using such opportunities to accuse his political opposition of the responsibility for the Luwero Triangle deaths and to threaten violent reprisals (Seftel, 2010: p. 286).

In spite of the frequent accusations of political oppositions at repeated exhibitions of the Luwero Triangle human remains, Museveni has steadfastly obstructed any demands from them to establish an independent commission of inquiry into the Luwero Triangle War (Opondo, 2010; Wanamba, 2010). Why is it that for almost three decades Museveni has persistently accused his political opposition of the responsibility of the Luwero Triangle deaths, while also repeatedly resisting demands to identify and prosecute the perpetrators? (Kalule, 2006). What intentions do Museveni's indefatigable accusations of political opposition of criminal responsibility have for the Luwero Triangle deaths serving his NRM/A regime? What has been the impact of Museveni's repeated defiance of his opposition's demands for an independent inquiry of the Luwero Triangle deaths? How have Museveni's actions manipulated and controlled the narrative and public memory of the Luwero Triangle War?

This paper examines the struggle to accurately present public history and historical memory in view of Museveni's transformation of the Luwero Triangle deaths into a practical political tool of ethno-xenophobia, demonization of political opposition and harnessing of ethnic and western donor legitimacy in order to govern. Emphasis on the Luwero Triangle deaths and the many sites of mass massacres must be seen as exposure and full disclosure that not only challenge the self-celebratory NRM/A narratives, but tell the truth to restrain manipulators of such tragedies who seek political relevance and personal aggrandizement (Kasibante, 2009). Luwero Triangle deaths as those strewn over the Ugandan countryside comprise integral parts of the country's tragic history of the abuse of NRM/A militarism and megalomania used to gain political power extra-constitutionally.

Whilst this paper is not an exhaustive examination of the history of the exhibited Luwero Triangle human remains, it recognizes that Museveni has infused these exhibits with powerful self-serving emotive narratives that carry visual, symbolic, and political meanings (Moser, 2010; Kateera, 2009). Museveni started the symbolic manipulation of exhibits by installing his statue, without genuine parliamentary discussions, at the military training facility that he attacked on February 6, 1981, sparking the Luwero Triangle War. The NRM/A organizers followed by annually scheduling celebrations around the country to mark the commencement of the Luwero Triangle violence and to threaten any critics of the so-called liberation struggles. Through these actions, Museveni is rewriting the history of the Luwero Triangle War by often describing his critics using derogatory and demeaning catchwords such as "the abatemu" (bloody killers), cockroaches, rotten mushrooms and venomous snakes. The tragic Luwero Triangle deaths, thus, have become a useful political tool for Museveni through which to demonize nearly all of his political opposition, especially those from northern Uganda as the main perpetrators (Museveni, 1997: pp. 117, 178). There is an urgent need to establish an independent commission of inquiry equipped with the tools of forensic science to carefully examine the Luwero Triangle human remains in an effort to construct a veritable narrative of the war (Moser, 2010).

\section{The History of the Human Remains of the Luwero Triangle War}

The mismanagement of the turbulent post-Amin's transitional period by the victorious Uganda National Liberation Front (UNLF) and the Tanzanian People's Defense Force (TPDF) laid the foundation of the Luwero Triangle War that produced the exhibited human remains. In particular, the UNLF was comprised of squabbling groups: Front for National Salvation (FRONASA), Save Uganda Movement (SUM) and Kikoosi Maluum (KM), each vying for leadership and political power (Museveni, 1997). The Moshi Conference in Tanzania produced a consensus President Professor Yusuf Kironde Lule, a Muganda, on April 11, 1979. Lule’s presidency was shortlived (Editor, 2009). Edward Rugumayo, Chairman of the interim parliament, the National Consultative Council (NCC) deposed him (Chekwech, 2012). President Godfrey Lukongwa Binaisa, also a Muganda, succeeded Lule in June 1979, sparking a protest by pro-Lule's Baganda supporters chanting: "we want Lule! Down with Binaisa" (Seftel, 2010). In a misstep, Binaisa proposed a bill that the 1980national election be organized under the um- 
brella of the UNLF (Ibid). The Uganda People’s Congress (UPC) and the Democratic Party (DP) accused President Binaisa of dictatorship and rejected the proposed national election bill. Paulo Muwanga, a Muganda, and Yoweri Museveni, a Munyankole, of the Military Commission deposed Binaisa (Museveni, 1997). Thus, the turbulent post-Amin's political environment disrupted the tenure of two presidents, Professor Lule and Binaisa, both of Baganda ethnicity in less than a year (Karugire, 1998: p. 87). Buganda perceived the adverse successive coups against their kinsmen as the continuation of alienation and humiliation that started with President Obote in the mid-1960s.

Uganda held the 1980 national election in the context of a dissatisfied and alienated Buganda, recriminations and uncertainty. Four political parties contested the general election: The UPC led by Apolo Milton Obote, the DP led by Paul Ssemogerere, the Uganda Patriotic Movement (UPM) led by Yoweri Museveni and the Conservative Party (CP) led by Mayanja Nkangi. In Mbarara North, Ankole region, three candidates contested the national election: Sam Kuteesa (DP), Gucwamaingi (UPC), and Yoweri Museveni (UPM). Sam Kutesa (DP) won with 15, 657 votes, defeating Gucwamaingi (UPC) votes of 12, 747 and Museveni (UPM) was last with 12, 682 votes (Monitor Editorial, 2005; Mugerwa, 2013). Museveni protested the outcome of the national election because of the perceived irregularities.

Indeed, the Commonwealth Election Observer group acknowledged irregularities on the conduct of the 1980 election. Nevertheless, Museveni's brother-in-law, Sam Kutesa (DP) won the parliamentary seat for Ankole North. Aggrieved Museveni, rather than abide by the recommendation of the Commonwealth Election Observer group, resorted to launching a guerrilla war, claiming that Obote rigged the election. Museveni could not instigate a war in Ankole where he did not have popular electoral support. He selected "The Luwero Triangle”, a geographic area of Buganda that comprises the districts of Luwero, Nakaseke, Nakasongola, Mpigi, Wakiso, Kiboga, Mubende and Mityana, for a guerrilla base. A convergence of historical, strategic and cultural factors influenced Museveni's choice and worked to his military advantage.

Luwero is strategically situated on the periphery of Kampala City, the capital of Uganda and homes to many international agencies and embassies. It was sparsely populated, according to the 1980 census, "having a population density of 86 persons per square kilometer” (Luwero District, 2010: p. 11). The nomadic Bahima pastoralists, Museveni's kinsfolk, who inhabit Luwero sympathized with him, provisioned 21, 000 heads of cattle, gathered intelligence and concealed the guerrillas (Kalyegira, 2005). The Bahima pastoralists would later join the NRM/A in large numbers to gain military experience with the objective of militarily returning to Rwanda (Museveni, 1997).

The Baganda also saw an opportunity in the irregularities of the 1980 that returned their nemesis UPC Obote to presidency. They had not forgiven Obote for the dissolution of the 1966 Kabaka Yekka (KY)-UPC alliance, the exile of Kabaka Mutesa to London, UK, and abolishing their monarchy (Leggett, 2001: p. 21; Kalyegira, 2005). When Amin overthrew Obote, the Baganda were euphoric and quickly embraced President Amin in 1971 (Mwenda, 2009). The Amin-Baganda honeymoon was short-lived because of President Amin's purges of many Baganda intellectuals, including murdering Attorney General Benedicto Kiwanuka. The Tanzanian People’s Defense Forces (TPDF) overthrow of Amin in 1979 returned Buganda's nemesis President Obote (UPC) to the state house, following the 1980 election. The poor management of the post-Amin's transition period inspired former President Luleto form the Uganda Popular Front (UPF), as an umbrella organization of prominent guerrilla forces to fight the Obote's regime. Prominent anti-Obote guerrilla groups including Federal Democratic Movement (FEDEMU) of David Lwanga, and the Popular Resistance Army (PRA) of Yoweri Museveni, joined the UPF (Jongman, 1988: p. 680).

After a series of disastrous military offensives against the UNLA, the assortment of Luwero Triangle guerrillas reorganized themselves under the National Resistance Army/Movement (NRM/A) of Museveni (Nganda, 2009). Museveni promised to restore the Baganda monarchy, return the confiscated cultural assets and end Baganda humiliation. He also affirmed his commitment to defeat President Obote by armed struggles (Mwenda, 2009). Brigadier Kasirye-Gwanga, and other Baganda rebel officers went on mobilizing Luwero peasants support for food, intelligence and concealment of the guerrillas from the UNLA, on the catchphrase "Kabakayaatutumye" (we are the king's agents) (Ibid). Museveni capitalized on the favorable security environment that the Baganda rebel officer cultivated and expedited Buganda Crown Prince Ronald Muwenda Mutebi secret tour of Luwero, boosting his credibility among the Baganda (Nampewo, 2015). The popular Baganda support Museveni enjoyed frustrated the UNLA counterinsurgency operations. This was the sad beginning of a fratricidal struggle involving the Baganda UPC youths allied with the UNLA fighting against the sympathizers of the NRM/A. 
Abdu Kasozi, a historian of Baganda origin, writes: "They [UPC youth, sympathizers and officials] collaborated with the UNLA soldiers by providing information and, in many cases, misinformation” (Kasozi, 1994: p. 115). He continued, "They decided which areas were to be raided and which people victimized and were thus a key element in the destruction of life and property" (Ibid). Captain Mica Kiribedda who had served in both the UNLA and then the NRM/A observes: "You should not forget after all, that those people were massacred for the blame that they were hiding the NRA guerrilla insurgents, including the NRM leader" (Kiribbeda, 2010). In the NRM/A guerrilla reprisal killings of UPC youths, Colonel John Ogole, commander of the UNLA $50^{\text {th }}$ Brigade fighting in Luwero said:

"As someone who commanded government troops in Luwero, I can authoritatively tell Ugandans today that we came across hundreds of dead bodies of mainly UPC activists who had been massacred in cold blood by Museveni’s NRA rebels” (Mugula, 2010).

The Baganda internecine warfare coupled with the UNLA versus the NRM/A war was the cause of the human tragedy and mass deaths of the Luwero Triangle.

As the UNLA intensified offensives against the NRM/A guerrillas in Luwero Triangle, Museveni made the fateful decision that will have long-term contentious implications to the causes of the Luwero Triangle War deaths. Museveni ordered his troops to evacuate Luwero, forcibly taking with them the civilian population. Museveni, writes: "I had to order the population to withdraw from Bulemezi area near Kampala, into Singo, the northern end of the Luwero Triangle, where they were very crowded and there was almost no food" (Museveni, 1997: pp. 113-117). Alex Bukenya, a young NRM/A soldier whose unit was charged with forcefully evacuating the Luwero civilian population writes: "The insurgent party...was conducting the evacuation. They moved north-east; a struggling mass of humanity ... of all descriptions” (Bukenya, 1992; Amaza, 1998: p. 92).

Amidst UNLA intense and sustained military onslaught, loudspeaker broadcast to the hostage civilian population to escape to the nearby government army units, the NRM/A guerrillas kept tight control over their hostages. This control was a tragedy for the hostage Luwero population. Bukenya observes: "they had been wondering through the wilderness for about a month now." Without Museveni providing for food, "hunger then started claiming its first victims, children and the very old and everyone else". In fact, “... the jungle proved at times more dangerous than the real enemy. Starvation was the outstanding cause of death" (Bukenya, 1992: pp. 64, 83). Major Rubaramira Ruranga, an NRM/A Officer, recalled the mass civilian death by starvation as "the lowest moment of his life... It was very sad for me to see people die of hunger. To date, I still remember those days and I shudder in shock” (Ruranga, 2004).

The NRM/A should not have evacuated the Luwero civilian population had its officers been diligent with intelligence and operational planning. Regrettably, forced civilian evacuation became necessary to provide human shields against the UNLA onslaught (Ibid). Irrespective of the human cost, Museveni writes, "for much of June and July 1983, we were busy evacuating the civilian population from Luwero and by the end of the year the whole of the area were depopulated" (Museveni, 1997). This misadventure of forceful evacuation without providing food, medicine and hygienic living environment facilitated excess unnatural civilian deaths. When Museveni ordered the Luwero civilian population to return home or go to government-run feeding centers (Ibid), the mass deaths was an already accomplished fact.

\section{Human Remains: Identity and Responsibility}

We may never know with certainty the identity, the total number and predominant causes of civilian deaths in the Luwero Triangle War from 1981 to 1986, when Museveni took power. Museveni pointed out, during one of his many visits to the World Bank in Washington DC: "There are 30 mass graves in Luwero. And each of the mass graves contains more than 2000 skulls. So that is a figure of about 70,000 skulls in just Luwero area alone. These were murdered extra-judicially" (Chappell, 1997). There is no doubt that the human remains provide an incontrovertible evidence of the mass casualties suffered in that war. Except the available opportunity for a forensic examination was lost when Museveni ordered the Luwero people to assist the NRM/A in exhuming the human remains from the 30 mass graves. Was the exhumation ordered to destroy evidence that may be useful for forensic examination? What is a political ploy to dupe the Luwero people by stocking ethnic xenophobia that is grounded in his self-serving narratives of the war? Who are the perpetrators of the Luwero war crimes? Are the perpetrators politically determined in a war some NRM/A officers characterized as a dirty war? A war where, 
some officers said, opponents must take responsibility for the NRM/A war crimes?

The cruel and crude NRM/A policy to haphazardly collect human remains did not only destroy the opportunity for utilizing the science of forensic examination, it also raised more serious questions to prominence. Were these human remains in mass graves buried by the UNLA or Museveni's NRM/A? Were these human remains buried at the many sites of the Luwero civilian hostages' transient internment camps created by Museveni to provide human shields from the UNLA military onslaught? Were the dead people non-combatant victims of crossfire battles between Museveni's NRM/A and the Obote's UNLA? Were they NRM/A or UNLA combatants? Why were they buried in mass graves, and on whose military order? We may never know with certainty the motivations of Museveni to issue that callous exhumation order, without any discussion in parliament and application of the science of forensics. What we do now know with certainty is the ethical, cultural, psychological, emotional and moral crises the Luwero human remains invoked. Most African cultures prefer burial after death, and few people would willfully donate their remains and that of their loved ones for public exhibit. An elder from Buganda observes: "when I saw the exhibit of human remains, I felt sad for it is anti-Baganda tradition to put on public display human remains. Our culture respects the dignity and rights of the deceased for a peaceful and descent burial. We utterly reject any form of displaying human remains” (Conversation I, 2013). Another Baganda elder wondered: "there was not a single public consultation in Luwero that I am aware of about what to do with the human remains that Museveni dug out for public exhibition” (Conversation II, 2013).

Other Ugandan community also shared the concerns of the Baganda elders for the Luwero human remains, not to be put on public exhibit but afforded a decent and deserving cultural burial. An elder from northern Uganda pointed out: "We are being demonized by Museveni as killers responsible for the mass deaths in Luwero and the public exhibit is presented as evidence of the accusation. We, from northern Uganda, have been demanding an international investigation into the Luwero Triangle mass deaths but Museveni has refused our plea” (Conversation III, 2013). While the macabre exhibit is instructive for the horrors of war, it has yet to tell us the identity of the victims, circumstance of death, the perpetrators and the unwillingness of the NRM/A to bring to justice those responsible for the crimes.

\section{A History of Museveni with Human Remains}

Contemporary debates on Luwero Triangle deaths must be solidly grounded in the knowledge of history, but not in the political myths Museveni has propagated for nearly three decades. It is imperative to revisit Museveni's undergraduate thesis, Fanon's theory of violence: Its verification in liberated Mozambique (1971), at the University of Dar-es-salaam, Tanzania, to appreciate how human remains are turned into political dividends. In glorifying violence and death, Yoweri Museveni writes, "violence alone, violence committed by the people, violence organized by its leaders, makes it possible for the masses to understand social truths and give the key to them". Museveni continued to show the potency of organizing violence and displaying human remains as tools of war. He writes:

In Mozambique, it has been found necessary to show peasants fragments of a Portuguese soldier blown up by a mine or, better still, his head. Once the peasants sees guerillas holding the head of the former master, the white man's head cold in death, the white skin, flowing hair, pointed nose and blue eyes notwithstanding, he will know, or at least begin to suspect, that the picture traditionally presented to him of the white man's invincibility is nothing but a scarecrow. However, once the peasants' passions are aroused, they usually swing to the other extreme; that all white men are devils...This position is not entirely wrong... (Museveni, 1971).

The despicable act of displaying severed heads of dead human victims for propaganda purposes must be seen within that context. Museveni and associates regarded the slaughtered white men with amused contempt. We must take seriously that this act was not a simple matter of youthful student bravado but deep-seated character trait. In fact, the public display of corpses was raised to a level of military and political policy in the NRM/A conduct of Luwero Triangle War. In his address to the delegates of the Third National Legal Aid Conference on March 10, 2015, Museveni boasts of ordering two soldiers who committed murder executed by firing squad and then publicly displaying their corpses to the civilian survivors to visit. The dramatic and tragic public execution and display of corpses reaped social dividends. Museveni observes, "the relatives of the civilians killed by our soldiers said these (NRA) are genuine” (Museveni, 1997; Kwesiga, 2015). 
Subsequent Ugandawar theaters from 1986 to the present time would experience their share of publicly exhibited human remains. In attempting to understand atrocities and war in a political debate on April 18, 2006, involving NRM Members of Parliaments from northern and eastern Uganda, Andrew Mwenda, a Kampala radio anchor for KFM 93.3, quoted the late Apolo Milton Obote. He said,

Museveni has for the last twenty three years fought different enemies in different regions of Uganda: Uganda National Liberation Armies (UNLA) in Luwero, Uganda People's Democratic Army (UPDA) in the north, West Nile Bank Front, Uganda People's Army of Peter Otai in Teso, Allied Democratic Forces (ADF) in western Uganda, and the Lords Resistance Army (LRA). In all these wars, the adversaries are different, the theaters of war different, the periods different. There are only two elements that are constant: Museveni on the one hand and massive atrocities against civilians on the other (Mwenda, 2006).

Mwenda asked:

What does this tell us? How can it be that all Museveni's adversaries in the different regions of Uganda, under different political organizations, and at different historical times fight the same way? Is it not logical that since Museveni and atrocities is the only constant, that it is Museveni who employs atrocities to win wars? (Ibid).

Certainly, the cynical manipulation of atrocities as political and military policy of warfare in Uganda implicate Museveni in atrocities, mass murders, war crimes and crimes against humanity, beginning from wars in Luwero Triangle and spreading to the rest of Uganda. It is important to cite a few cases: "terror and massacres of Muslims in Ankole in June 1979" (Uganda Government, 1981: p. 31), “abduction and assassinations of civilians” (Amnesty International, 1981) and "attacks on civilian vehicles" (Africa Research Bureau, 1981: pp. 1-3: 6289BC). The late Dr. Andrew Lutakome Kayira, eyewitness report after meeting Museveni at the NRA command post in Luwero said:

I saw over 50 freshly cut off heads bleeding surrounding the tent in form of the ring and Museveni was sleeping inside. When Museveni got out of his tent, he asked: "Do you see all these people!This is how I deal with people who don’t agree with me (Muwanga \& Gombya, 1991).

The use of atrocities and public displays of corpses would become bolder as the northern insurgencies drew longer, changed phases and emphases; andsenior NRM/Amembers refashioned new political parties. In the northern Uganda war between the NRM/A and the Lord's Resistance Army (LRA) of Joseph Kony, Dr. James Rwanyarare (UPC) accused Museveni's NRM/A of cooking 28 massacred civilians in pots in Gang pa Aculu in Omot, Pader, Northern Uganda, on October 28, 2002 (Atuhaire, 2002) and shifting the blame to the LRA. The blame for the various atrocities would metamorphose into a bold political strategy to demonize, blackmail, malign and obstruct justice for the purpose of NRM/A legitimization and governance. In Buganda particularly Luwero, the ferocity of the exploitation of Luwero deaths to silence and malign any political oppositions group that drew attention to the genocide in northern Uganda would increase exponentially.

\subsection{Museveni, the Luwero Triangle Human Remains and Western Donors}

The exploitation of the Luwero Triangle human remains, as a weapon to muffle western donors' criticisms of the Museveni regime's human rights records, is here exemplified as the most lethal weapon of war beyond dispute in the conflicts in Uganda. Whenever Museveni's NRM/A regime comes under attack for human rights violations, he would personally take ambassadors accredited to Uganda to the Luwero Triangle mass graves, where he would officially vilify "killers" and make more accusations to justify his human rights records. On May 18, 2006, Henry Mukasa, a New Vision journalist, quotes Museveni:

The purpose of your coming here with me is because some of your countries have interest in the human rights situation in Uganda especially European countries. As human beings, it's okay but you should do so with knowledge (Mukasa, 2006).

Museveni continued:

Because you don't know, instead of being part of the solution, you can be part of the problem. To cure this, I am going to partner with you to enable you to know Uganda so that when you talk, you don't talk from 
ignorance (Ibid).

A selected group of NRM youths were assembled to heckle the diplomats at Nakaseke. The NRM/A youth hecklers jeered:

They tell lies, false propaganda, trying to turn black into white about human rights in Uganda and these (ambassadors) become the loudspeakers (Ibid).

The convergence of NRM youth hecklers and official propaganda of Luwero deaths as a political tool of blackmailing western diplomats worked, to some extent. In western capitals and official relations, Museveni's human rights abuses are being carefully sanitized and the narratives are scripted to exclusively implicate NRM/A's political oppositions, in spite of glaring facts to the contrary. Any attempts to raise the violations of the NRM/A regime by critics are usually ignored and deemed unnecessary and malicious. The NRM/A regime stoked ethno-xenophobic hate and anger of victims against alleged perpetrators. The exploitation of Luwero Triangle human remains became the official NRM/A trump card and policy for dealing with political oppositions of the regime, and predominantly those from northern and eastern parts of Uganda.

\subsection{Blackmailing Political Oppositions and Critics of the NRM/A Regime}

The late Ugandan President Apolo Milton Obote was an ardent critic of Museveni's human rights record. In Notes on the concealment of Genocide, he accuses Museveni of committing atrocities against Ugandans in Luwero Triangle, while masquerading as the Uganda National Liberation Army (UNLA) (Obote, 2009; Okanya, 2009). President Museveni fired back that Obote must answer for the atrocities of the UNLA, in Luwero. Obote's accusation of Museveni's NRM/A was corroborated by the Luwero Triangle report of A.J. McIlroy of the The Daily Telegraph, London.

And Mr. Nusur Jogojogo, the area chief, later told me [Mcllroy]:

Three months ago, seven villagers were killed; three men and four children were shot or hacked to death by men with pangas (machetes) and guns. They were bandits; there is no doubt about that. Some of them were from our village. They were dressed half way, I mean they were in Army and civilian clothes, all mixed up... By the time the soldiers arrived, the people had fled into the bush. Whatever possessions they left behind, were looted by the soldiers (McIlroy, 1984).

Colonel Kutesa, a serving UPDF officer, corroborated McIlroy's report. He writes: "they (NRA) dressed in UNLA uniform and green coats, they (his NRA colleagues) mingled with the government soldiers and infiltrated...” (Kutesa, 2006).

Colonel Kutesa had made such a claim before he published his book. During an interview with William Pike on Capital Radio in Kampala in 1995, in a program called Desert Island Disc, he told Pike that he was "a Lieutenant in the UNLA but as an NRA infiltrator whose mission was to undermine the credibility of the army from within.” Similarly, the Monitor Newspaper of April 15, 2005, carried a report that as officer in-charge of the roadblock at Konge, Kutesa would harass civilians, rob them of their money and kill some (Monitor Newspaper, April 15, 2015).

It went on to say that Generals Kahinda Otafire and Elly Tumwine boasted at the funeral of the late Adonia Tiberondwa of similar kind of machinations and deception to delegitimize the regime of Obote and win local support. Certainly, atrocities committed against civilians with the purpose of achieving a political and military victory worked, especially when the adversary took the blame for it. As an effective weapon, the use of atrocities for political gain would become clearer during the last political competition between incumbent President Museveni and Besigye, a former physician to Museveni during the NRM/A guerilla was in Luwero Triangle. Besigye and other former members of the NRM/A high command who fought alongside Museveni against the UNLA were blamed for the Luwero Triangle atrocities. Yet these military commanders were firsthand witnesses to the deaths and destruction of the war Museveni launched after losing the election to a DP candidate. The former colleagues grew furious and warned Museveni to stop blackmailing them for cheap political ends.

\subsection{Blackmailing Former NRM/A Guerrilla Colleagues, Turned Political Competitors}

In the electoral challenge of 23 February, 2006, Museveni blamed the Forum for Democratic Change (FDC) 
leaders: Colonel Kizza Besigye, Major General Mugisha Muntu, Major Rubaramira Ruranga and John Kazoora, for the atrocities in Luwero Triangle. Put simply, shifting the blame for Luwero Triangle deaths upon his former guerilla colleagues served as a strategy to shift internal alliance and deny them legitimacy in the southern part of the country; and Museveni, unblemished, remained the defender of the southern ethnic political power elite.

The FDC military officers who served loyally under Museveni's NRM/A and witnessed the ferocity of the war responded in anger. Major Ruranga, of the UPDF (former NRA), who fought alongside General Museveni during the Luwero war from 1981-1986, when the atrocities were committed, writes in the New Vision, July 12, 2005: ...the killings in Luwero during the civil strife must be blamed on the National Resistance Army (NRA) that started the war (Maseruka, 2005; Bogere, 2007). Major Ruranga continued:

I hear many people claiming that Obote killed people in Luwero. Obote could have done something wrong but Museveni did many bad things. I was in NRM with Museveni and people in Luwero were used as shields by us. I saw many people die, not only from bullets but also from hunger (Maseruka, 2005; Bogere, 2007).... So for someone to say NRA did not kill people and that former regimes were more bloody than this one is not true because there is no war where two sides are shooting in a cross fire and only one side gets casualties (Bichachi, 2012).

Another demonized retired UPDF (former NRA) military officer, Kazoora, Kashari Member of Parliament, who fought alongside Museveni spoke of his personal dossier on the 1981-1986 Luwero Triangle War on November 8, 2005, while responding to Museveni's accusation of Luwero deaths. Kazoora writes, "Some of us have deliberately kept quiet about Luwero war ...it would be wrong for one side to accuse the other of committing crimes in Luwero". He lamented, "I thought that we were fighting for democracy. Little did I know that we were fighting to make one man, Museveni, a life President” (Kazoora, 2005).

Colonel Besigye, presidential torchbearer for FDC, and former personal physician to General Museveni, who fought alongside Museveni during the Luwerowar, supports and emphasizes Kazoora and Ruranga’s statements. In an interview with Andrew Mwenda, on KFM's Tonight on October 27, a day after he returned from exile, Colonel Besigye acknowledged that the NRM/A, which he was part of, could share the blame in the Luwero killings.

Colonel Besigye said:

In a war, all parties are there to kill either in defense or aggression. We need to investigate who killed who, for the purposes of resolving future conflicts. It's not good for one party to lay charges on others. People (forces) of all parties could be culpable (Besigye, 2005).

The FDC former NRM/A military officers-turned-regime political critics unleashed the wrath of President Museveni's press office. Responding with more accusations and blame for atrocities, Ofwono Opondo, published an opinion piece in the New Vision, on August 26, 2005, in which he shifts the blame for atrocities onto General Muntu, the longest serving Army commander of the NRA/M, who is currently in-charge of FDC mobilization, and Besigye, as FDC presidential candidate.

Opondo writes:

If Muntu was seeking comprehensive justice for all, how come he is not talking for the 39 who died (read roasted alive) in Mukura wagon (Teso), Bur Cor (Acholi, where scores of people were buried alive), when he was Army commander?

He continues,

Indeed, the politicians from northern Uganda, including ministers like Omara Atubo and Zackary Olum, whose sober accounts of torture while being arrested and in detention between 1990 and 1993, should not seek redress lest they (meaning Muntu and Besigye) are called to judgment...And further, FDC leaders falsely believe that 1986-98 when they were the bosses is now so far away, and it would be better to forget (Opondo, 2005).

Opondo wanted to blackmail General Muntu into silence when he referred to atrocities committed against civilians in eastern and northern Uganda by NRA, for which Muntu bore command responsibility. He was silent on the fact that as president and commander-in-chief of the NRM/A, General Museveni bore the final command responsibility. In his address to the Langi and Acholi Resistance Councils (RCs) and elders, Museveni had once 
admitted to atrocities under General Muntu. He said:

Sometimes, our own undisciplined soldiers took advantage of the breakdown of law and order caused by the rebellion and committed atrocities against the civilian population (Museveni, 1994).

The admission followed similarly of "mass rapes and other atrocities by the NRA" (New Vision, 1988) for which Muntu and other retired officers were in active service and gained rapid promotions.

The open acknowledgment by President Museveni, General Muntu, Colonel Besigye and the other retired UPDF officers have not been followed with criminal convictions and a truth and reconciliation commission. We must be clear that the blackmailing of General Muntu, Colonel Besigyeand others was because they would deny Museveni the free utility of atrocities for political legitimacy, to consolidate an ethno-xenophobic and militarist regime and to conceal the current genocide in northern Uganda.

\subsection{Consolidating an Ethno-Xenophobic and Militarist State, a Genocidal and Divisive Administration}

By consistently inciting maniacal feelings of revenge and contempt, which functions to support the northern genocide, Museveni's NRM/A has successfully divided the country along ethnic lines. Andrew M. Mwenda writes:

It does not pay for other MPs to follow colleagues from Acholi, Lango and Teso in walking out of parliament because that does not advance their electoral fortunes. The war in northern Uganda has therefore been contained in the prism of an ethnic conflict affecting only the Acholi, or Langi, and the Iteso, rather than a national problem (Mwenda, 2004).

Mwenda continues his observation in The Monitor, May 6-12, 2006:

The war in the north has always been used to rally people in the south around the NRM and Mzee (Museveni) during election times by spreading imaginary fears that "northerners want to come back to power to kill us." This cynical and highly ethicized politics was effectively employed during the 1996 presidential election campaigns. Some FM radio stations ran adverts of soldiers with a northern accent torturing and killing people at roadblocks. Newspapers also carried adverts of skulls... But to keep the ethicized campaigns against the north, it is politically necessary to brand them (political competitors) agents of "those northerners" by linking them either to Obote or Kony. It is this process of demonizing people from the north...that is the basis of Mzee's regime (Mwenda, 2006).

The consolidation of ethno-xenophobic policy thrives on the devious NRM/A regime's self-celebratory memory. This is often invoked in the name of nation, ethnicity and perpetuates the need for revenge. The lifeblood of the ethno-xenophobia is deliberately manufactured myths to conceal complicity in genocide against the northerners. Its practical policy is militarism and militarist ethno-xenophobic and chauvinistic governance.

The 41-page report entitled, Northern Uganda: Understanding and Solving the Conflict, by the Brusselsbased International Crisis Group (ICG) released on April 15, 2004 agrees:

The war helps him justify and maintain the status quo in Uganda politics, denying his opposition a power base and offering numerous opportunities for curtailing freedom of expression and association in the name of "the war against terrorism” (International Crisis Group, 2004).

The State House acting presidential press secretary rubbished the report describing it as "ridiculous and the work of research tourists.” To be clear, Martti Ahtisaari, former Finnish President chairs the ICG and Gareth Evans, former Australian Foreign Minister, run the organization. Both have solid credentials in democratic governance.

Similarly, a political science professor, Joel D. Barkan, of the University of Iowa, writes in The Weekly Observer newspaper on 4 August 2005:

The war has served Museveni's political purpose in two fundamental ways. First, it has helped him consolidate popular support across southern Uganda, and particularly among the Baganda.... Second, the war has shored up Museveni's political base within the UPDF; the UPDF has always been a pillar of the regime (Barkan, 2005). 
President Museveni supports Professor Barkan when he added that the high-ranking military officers needed the war to amass wealth, hence consolidating his political base. Museveni said, "It is true that in the past army officers were doing business out of the suffering of Acholi and they did not want it (the war) to end” (Museveni, 1996). The tragedy of Acholi people has become a necessary Trojan horse to accumulate wealth among the high-ranking military officers. A government's own investigation into the Ghost Soldier reports by Mbabazi/Generals Tinyefuza and Saleh, showed that about 50 percent of the UPDF payroll was inflated with "ghost soldiers” (Bichachi, 2012; Nyakairu \& Kasyake, 2003; Abdallah, 2004). Unfortunately, no prosecution has even been undertaken; and, most of the implicated officers have gained rapid promotions.

It follows that the longer the war perpetrated in Acholil and was prolonged by Museveni's NRM/A, the more the Acholi people were blamed for the Luwero Triangle deaths. The war imposed on the Acholi people was fabricated as being the result of the mass deaths committed in Luwero Triangle; instead of the Acholi people remaining as a formidable political opponent of the NRM/A regime (Mugula, 2010). It follows that numerous accusations have been concocted to implicate the Acholi people and to justify their decimation by the NRM/A regime. John Muto-Ono P'Lajur, a journalist for The Monitor newspaper, reports on April 5, 2004, of a Luwero meeting from March 4-7, to which Acholi elders and religious leaders were invited to apologize to the Baganda victims. The Acholi leaders rejected the invitation saying that they never fought the Baganda, even in ancient history. Many Acholi councilors described the meeting as "unfair and meant to justify the ongoing war” (genocide) against them (Muto-Ono P'Lajur, 2004).

Gulu Local Council-V Chairperson (LC-V), Lieutenant Colonel Walter Ochora (RIP), an Acholi and former commander in Luwero with the defunct UNLA, turned a staunch supporter of the NRM/A in Gulu, said, "Neither the Acholi nor the Obote army would take responsibility for the killings” (Muto-Ono P'Lajur, 2004). As a former soldier with the UNLA, he was the enemy of the NRA rebels and fought long and hard battles to kill the NRM/A rebels of Museveni.

Colonel Kutesa, a former officer of the NRM/A supports Ochora's observations. Kutesa writes that he fought the bloody battle of Kampomera against Lieutenant Colonel Ochora; both former outfits were arrayed against the other. Kutesa calls Ochora a personal friend with whom he often shares memories of their concerted attempts to kill each other. He also speaks of fighting against Colonel Ogole of the UNLA at Kamboga, where many combatants perished (Editor, 2006).

Colonel Kutesa writes vividly of death and destruction in the Luwero Triangle War. However, Museveni would rather not call these fighters to account for Luwero Triangle deaths; neither does he investigate or punish these officers for Luwero Triangle deaths. In the context of political demonization to retain power at all costs, the genocide against the Acholi people, politically opposed to the NRM/A regime, would continue under the propaganda machinery that extols Museveni as ushering in the era of "peace and tranquility", "economic growth", and the "golden boy of the west" and "the savior of Uganda from ruin".

However, one thing remains clear to critical observers. Kevin Ogen Aliro, a journalist with The Monitor newspaper reports why some people are reluctant to see the genocide in Acholi. He writes:

I particularly understand the dilemma of some ordinary Ugandans, who after many years of torture and oppression, don't want to believe that the UPDF (former NRM/A) ...could even dream of such atrocities against any Ugandan... Ugandans are victims of self-denial and its associated symptoms. In their subconscious...they know that UPDF, like previous armies, are capable of all and worse.

Aliro gives a personal reminiscence:

I was like such Ugandans. There were times when I would never believe the UPDF would hurt a fly. I dismissed the Bur Coro incident (in which innocent human beings were buried and smoked in a pit) as an isolated case of indiscipline.

In his conclusion about the silence surrounding the genocide in Acholi, he said:

Deep inside, we (journalists) were also afraid. Afraid of the known consequences of publishing anything that may be deemed by the powers that be as "damaging to the image of Museveni's sacred cow, the NRA (now the UPDF).” Hundreds of other incidents came and went, most unreported (Aliro, 1999).

The decimation of the Acholi population is the result of lethal cocktail of deceit, demonization and ethno-xenophobic hate, in which western governments and the United Nations became complicit. Genocide was 
unfolding under our watch as we save Darfur, a less severe and shorter duration tragedy, than that in northern Uganda. There was ongoing genocide against the Acholi people, political oppositions of the NRM/A regime, in northern Uganda.

\subsection{Luwero Triangle Deaths as a Necessary NRM/A Electoral Tool}

The Luwero Triangle atrocities and mass deaths is being used to build a vanguard of people often unwilling to hear the narratives that challenge NRM/A political myths and call into question comfortable and self-righteous assumptions of the NRM/A regime's non-complicity.

Badru Wegulo, Chairman of the UPC Constitutional Steering Committee, challenged Museveni to investigate the Luwero Triangle deaths. He observes that whenever election time nears, Museveni raises Luwero Triangle deaths to prominence. Skulls and other human bones are dug up; the staccato of machine gun fire and eerie torture cries play on the national radio to instigate ethno-xenophobic hatred and win votes for Museveni. Wegulo said:

If the government is concerned about Ugandans, we demand that an international commission be set up to investigate who is responsible for the killings in Luwero (Mpagi, 2005).

The NRM spokesman, Ofwono Opondo, answered: "there is no need for a Truth and Reconciliation Commission and we shall not have one anyway" (Ibid). Concerned and irked by the continuing exploitation of Luwero Triangle deaths for political blackmail by the NRM/A, a Member of Parliament for Samia Bugwe North, insisted: "We are tired of Luwero and the demonization...They have stretched us far enough...". Ofwono Opondo, once again, dismissed the call for international investigation. He said,

We do not need the international community to come and tell us who killed people in Luwero either. The survivors are there and they can tell us who destroyed their homes (Monitor Online, 2005).

Early 2006, before ambassadors and high commissioners accredited to Uganda, Museveni dismissed a suggestion to have the alleged perpetrators tried for Luwero Triangle deaths and punished. Museveni said:

[We] did not follow up culprits who fled to European capitals from where they are issuing invectives on [my] government to paint it black. [It $\}$ was deliberate not to ask for extradition of presidents Idi Amin and Milton Obote to allow wounds to heal. The devils we chased away here ran to Europe from where they became angels (Museveni, 2006)

When Olara Otunnu, a former Uganda diplomat at the United Nations, a former Under-Secretary for Children in Armed Conflict at the United Nations, indicated that he would return to Uganda to lead the UPC party, Museveni took European ambassadors to Luwero where he accused Otunnu of the responsibility for the LuweroTriangle deaths. Olara Otunnu, the author of various articles: "Northern Uganda: Profile of A Genocide" (Otunnu, 2006) and "The Secret Genocide” (Otunnu, 2009) sought in his writings to expose Museveni's demonic agenda for the ongoing war that he termed genocide in northern and eastern Uganda. Despite Museveni's accusation, Otunnu returned to Uganda and was elected as the President of the UPC in 2010. As the UPC leader, he renewed his call for the establishment of an independent commission of inquiry into the Luwero Triangle deaths (Administrator, 2010). General David Tinyefuza (now Sejusa), Coordinator of Intelligence Agencies threatened Otunnu: "We will crush you if you persist in speaking about the Luwero Triangle killings." He warned, "don't play with the blood of our people". Ugandan opposition rallied to Otunnu's defense. Micheal Mbikke, President of Social Democratic Party was more emphatic: "General Tinyefuza's mid-week ing .... is an attempt to intimidate” Otunnu into silence” (Khisa, 2010).

If Museveni wanted to allow the Luwero Triangle wounds to heal, why is it that when the legitimacy of his regime to govern is slipping, then Luwero Triangle atrocities are remembered and the "wounds" opened? (Mayega, 2006). Certainly, the concealment of truth and perpetration of atrocities through [i] shifting the blame and [ii] using truth telling merely as tactical but not principled communication, yield handsome dividends to legitimize President Museveni's governance.

As Museveni consolidated his regime and gained strong backing of a prominent western government in the war on terror, he admitted that the NRA killed Ugandans or UPC supporters in the struggles for political power. Ugandans were not surprised by Museveni's public admission of culpability in the bloody guerrilla war in Luwero Triangle from 1981 to 1986. There was no doubt whatsoever in the minds of Ugandans that the NRM/A 
guerrillas did their fair share of killing Luwero Triangle civilians during the insurgency (Lucima, 2012). The central unresolved demand of the opposition groups is to establish the identity of the Luwero Triangle victims, apprehend the perpetrators and prosecute them in a competent court of law. So far, Museveni has obstructed every possible opportunity that could lead to the quest for justice for the Luwero Triangle victims. He is shamelessly exploiting the Luwero human remains for the political purposes of harnessing ethnic-centered NRM/A regime legitimacy.

\section{Conclusions}

The manipulation of Luwero Triangle deaths has become a powerful political and military weapon in the hands of NRM/A political and military elite to mobilize ethno-xenophobic hate and chauvinistic nationalism against political oppositions, especially against the Acholi population. It has been used to justify genocide, and, among other political critics, it is useful to demonize to consolidate a militarist and ethno-xenophobic power base. Luwero Triangle deaths are useful for the preservation of NRM rule, as the NRM regime struggles to legitimize its governance and entrench itself in power. The use of Luwero Traingle deaths as weapons of malice to malign oppositions and retain power has replaced the search for justice. At the hand of Museveni, it has become an actual commodity, a promissory note and a currency to buy political support. The success of manipulating the Luwero Triangle deaths is reflected in denying a truth and reconciliation commission investigation, forensic examination, refusing an independent international inquiry into Luwero Triangle deaths and prohibiting retired NRM/A military officers from freely writing about their experiences in the Luwero Triangle War.

Ugandans must understand that Museveni uses atrocities to get to power; uses atrocities to impede democratization that threatens his hold on power, by shifting the blame on his political oppositions like the UPC and FDC. Museveni was successful in using atrocities against Obote in the Luwero Triangle War; against Besigye in the last two general elections; in the war against rebels in eastern and northern Uganda since 1986, and in the Democratic Republic of the Congo. He was also successful in maliciously shifting the blame for the war in northern Uganda upon western donor nations who were contributing 52 percent of Uganda's Gross Domestic Product (GDP), but who also allied with Museveni for strategic control of Africa.

Finally, the history of NRM/A regime is a narrative of victimization, violence, massacres, genocide and exploitation of death to give political life to the NRM/A regime. Mass deaths, deception and violence disguised as concern for the sanctity and protection of life, are necessary for NRM/A legitimacy to govern. Sadly, the $\mathrm{NRM}$ /A regime was never about the promotion of democracy and human rights, but domination resting on coercion, massacres, beatings, mutilations, humiliations, rape and genocide. While this analysis does not offer insight into NRM/A psychopathological deception, lies and obsession with death and massacres, one point must remain clear: whatever direction our current debate takes us, it must go down the path of broader public education, investigation and learning the truth about Museveni's complicity in the Luwero Triangle mass murders and the horrendous destruction of lives in eastern and northern Uganda, Rwanda and the Democratic Republic of the Congo (DRC). It must also emphasize the shameless duplicity with which Museveni has harnessed Luwero Triangle deaths for political dividends. In fact, what we understand today as Luwero Triangle deaths is a legacy of the NRM/A engineered war on February 6, 1981, against the defunct UNLA of the late Apolo Milton Obote, nearly three decades. The exploitation of human remains by Museveni to reap political dividends suggests that progressive human rights scholarships based on the Luwero Triangle War must examine the relationship between militarized political power and rights of the dead including their posthumous dignity and respectful treatment. Ugandan political elites need to restore the dignity and respect for the dead by engaging a reputable and independent commission of inquiry, tools of forensic science, truth and reconciliation commission.

\section{References}

Abdallah, H. (2004). Govt Blocks Tinye Ghost-Soldier Report. The Monitor, April 6.

Administrator (2010). Interview: Tinyefuza behind Horrific Crimes in Luwero-Otunnu. The Observer, April 5.

Africa Research Bureau (1981). Africa Research Bulletin, December 1-31: 6289BC.

Aliro, K. O. (1999). Why Some People Are Reluctant to See Genocide in Acholi. The Monitor, May 18.

Amaza, O. (1998). Museveni's Long March from Guerrilla to Statesman. Kampala: Fountain Publishers.

Amnesty International (1981). Uganda: Breaking the Circle. London, August 16.

Atuhaire, A. (2002). Mutale Denies UPC Claim on North Massacre. The Monitor, November 14. 
Barkan, J. (2005). An African Success Story?.Weekly Observer, August 4.

Besigye, K. (2005) KFM93.3 Tonight’s Radio Talk Show. Kampala, October 27.

Bichachi, O. C. (2012). From Ghost Soldiers to Ghost Investors. The Observer, May 4.

Bogere, H. (2007). NRA, UNLA Killed People in Luweero, Says Ruranga. Daily Monitor, October 11.

Bukenya, A. (1992). Inside Luwero Triangle. Kampala: Kitata Publishing and Trading Co. Ltd.

Chappell, P. (1997). Our Friends at the Bank. (Video: 85 Minutes/Color/). New York: Icarus Film (Starts at 32:53 Minutes).

Chekwech, A. (2012). Exit Lule, Enter Binaisa, the Consulting Leader. Daily Monitor, October 19.

Conversation I (Participant Requested Names Withheld): Part of the Conversation I Had with an Elder from Uganda about the Luwero Mass Deaths and Public Display of Human Remains. The Meeting Took Place in Washington DC, USA in April 2013.

Conversation II (Participant Requested Names Withheld): Part of the Conversation with an Elder from Uganda about the Luwero Triangle Mass Deaths and Public Displays of Human Remains. The Conversation Took Place in Washington DC, USA in April 2013.

Conversation III (Participant Requested Names Withheld): Part of the Conversation I Had with an Elder from Uganda about the Luwero Triangle Mass Deaths and Public Display of Human Remains. The Conversation Took Place in Washington DC, USA in April 2013.

Editor (2006). Epic Battles as Ochora Took on Kutesa and Ogole Encountered Saleh. The Monitor Online, May 20. http://www.monitor.co.ug/insights/ins05215.php

Editor (2009). Why Yusuf Lule Was Removed from Office after Only 68 Days. Daily Monitor, Friday, April 17.

Editorial (2005). Uganda: Museveni Challenges Kuteesa’s Win in Court. The Monitor, October 9.

International Crisis Group (ICG) (2004). Northern Uganda: Understanding and Solving the Conflict. Brussels.

Jongman, A. J. (1988). Political Terrorism: A New Guide to Actors, Authors, Concepts, Data Bases, Theories, and Literature. Piscataway, NJ: Transaction Publishers.

Kalule, M. (2006). Uganda: Establish a Truth and Reconciliation Commission Now. Pambazuka, May 31.

Kalyegira, T. (2005). Twenty Years Later: Dr. Milton Obote Still President of Uganda. The Monitor, June 24.

Karugire, S. R. (1998). Roots of Instability in Uganda. Kampala: Fountain Publishers.

Kasibante, R. A. (2009). Who Disturbed Our Precious Sleep in the First Place. Monitor Online, April 8.

Kasozi, A. B. K. (1994). The Origins of Political Violence in Uganda. Kampala: Fountain Publishers.

Kateera, M. H. (2009). Museveni and the NRM Revolution. Kampala: Fountain Publishers.

Kazoora, J. (2005). MP Kazoora Documents 1981-86 Luweero War. The Monitor, November 7.

Khisa, I. (2010). Uganda: Opposition Defy Tinyefuza’s Warning. The Monitor, March 21.

Kiribbeda, M. (2010). Uganda’s Political Turmoil Post Idi Amin. London: Author House.

Kutesa, P. (2006). Uganda’s Revolution: How I Saw It. Kampala: Fountain Publishers.

Kwesiga, P. (2015). I Was Once “Chief Justice” —Museveni. New Vision, August 10.

Leggett, I. (2001). Uganda: An Oxfam Country Profile. Oxford: Oxfam, Great Britain.

Lucima, O. (2012). When Will Luwero Truth Be Told in Full? Monitor, July 25.

Luwero District (2010). Luwero District Statistical Abstract for 2008/2009.

Maseruka, J. (2005). Ruranga Defends Obote on Luweero. New Vision, July 11.

Mayega, H. (2006). Museveni Should Stop Opening Old Wounds for Political Expedience. Monitor Online, May $28,2006$.

McIlroy, A. J. (1984). Uganda Killers “Are Disguised” as Soldiers. Daily Telegraph, London, on August 16.

Monitor Newspaper (2005). Museveni Uses War to Keep in Power. April 15.

Monitor Online (2005). Quoting Ofwono Opondo in Letters-Uganda Politics and the Northern War. June 22.

Moser, S. (2010). The Devil Is in the Detail: Museum Displays and the Creation of Knowledge. Museum Anthropology, 33, 22-32.

Mpagi, C. M. (2005). Probe Luweero Massacres. The Monitor, June 22.

Mugerwa, Y. (2013). How MPs Became “Fathers of the House”. Daily Monitor, October 31.

Mugula, S. (2010). Museveni Used Luwero War to Spread Hatred. Uganda Correspondent, September 20.

Mukasa, H. (2006). M7 Takes Envoys to Luweero. New Vision, May 18. 
Museveni, K. Y. (1996). Has Museveni Hang His Gloves on Corruption? New Vision, November 29.

Museveni, Y. (1994). Published Facts. New Vision, March 28.

Museveni, Y. K. (1997). Sowing the Mustard Seed: The Struggle for Freedom and Democracy in Uganda. London and Basingstoke: Macmillan Publishers.

Museveni, Y. T. (1971). Fanon's Theory of Violence: Its Verification in Liberated Mozambique. In N. M. Shamuyarira (Ed.), Essays on the Liberation of Southern Africa (pp. 1-24). Dar es Salaam: Tanzania Publishing House.

Muto-Ono P’Lajur, J. (2004). Acholi: Don’t Blame Us for the Luweero Massacres. The Monitor, April 5.

Muwanga, L. S., \& Gombya, H. (1991). The Pearl of Africa Is Bleeding: We Shall Massacre Them. Växjö: Publisher Not Identified.

Mwenda, A. (2006). KFM 93.3, April 18. Radio Discussion Involving NRM Ugandan Members of Parliament.

Mwenda, A. (2009). Museveni-Buganda’s Bush War Deal: Who Is Telling the Truth? The Independent, September 29.

Mwenda, A. M. (2004). The Link between Movement and War. The Monitor, April 26.

Mwenda, A. M. (2006). Without Mincing Words. The Monitor, May 6-12.

Nampewo, A. (2015). 60 Years in the Life of a Kabaka. The Monitor, April 13.

New Vision (1988). Opinion-Government Commits Atrocities. January 1.

New Vision (1988). Opinion-Some NRA Soldiers Were Undisciplined. February 22.

Nganda, S. I. (2009). My Story: My Advice Made Museveni Succeed Lule as NRM Chief. The Weekly Observer, August 17.

Nyakairu, F., \& Kasyate, S. (2003). Uganda: Tinyefuza Summons Kazini. The Monitor, December 29.

Obote, A. M. (2009). Notes on the Concealment of Genocide. August 30, 2015.

http://www.upcparty.net/obote/genocide.htm

Okanya, A. (2009). UPC Calls for Truth Commission. New Vision, May 28.

Opondo, O. (2005). Muntu, Besigye Share Blame for the Mistakes. New Vision, August 26.

Opondo, O. (2010). Don't Believe Otunnu, He Is Revisionist. Office of the President: Republic of Uganda: Uganda Media Centre. http://mediacentre.go.ug/opinion/don\%E2\%80\%99t-believe-otunnu-he-revisionist

Otunnu, O. A. (2006). Northern Uganda: Profile of a Genocide. The Monitor, January 8.

Otunnu, O. A. (2009). The Secret Genocide. Foreign Policy, October 19, 44-46.

Ruranga, R. (2004). Quoted in Editorial, NRM Bush War Memories: Maj. Ruranga Kept Mutale. Daily Monitor. February 9. Seftel, A. (Ed.) (2010). Uganda: The Bloodstained Pearl of Africa and Its Struggle for Peace. Kampala: Fountain Publishers. Uganda Government (1981). Report of the Human Rights Commission of Inquiry into Violations of Human Rights.

Uganda Radio Network (2012). Luwero War Mass Graves Rotting Away. http://ugandaradionetwork.com/story/luweero-war-mass-graves-rotting-away\#ixzz3jqPw5afP

Wanamba, R. (2010). Tinyefuza Warns Otunnu: We Will Crush You. Daily Monitor, March 18. 